Tuah Talino

Tahun XIV Volume 14 Nomor 2 Edisi 4 Desember 2020

ISSN 0216-079X E-ISSN 2685-3043

Balai Bahasa Kalimantan Barat

\title{
NGAMBOL: UNGKAPAN KEMARAHAN MASYARAKAT MELAYU PONTIANAK KALIMANTAN BARAT
}

\section{NGAMBOL: ANGER EXPRESSION OF PONTIANAK MALAY SOCIETY OF KALIMANTAN BARAT}

\author{
Syarifah Lubna \\ lubna_alkadrie@yahoo.com \\ Balai Bahasa Kalimantan Barat
}

\begin{abstract}
ABSTRAK
Lima ungkapan masyarakat Melayu Pontianak Kalimantan Barat dalam mengekspresikan kemarahannya adalah: nyumpah, nyeranah, beleter, pendek tongkeng dan ngambol. Semuanya berbeda dalam penerapannya sehari-hari. Ngambol adalah ungkapan kemarahan yang sifatnya ironi karena tidak mengekspresikan kemarahan dalam bentuk langsung melainkan mengikuti lawan bicara disertai ekspresi wajah serta tekanan suara yang khas dan menunjukkan ketidaksetujuan pada yang sedang diucapkan. Ngambol menjadi fokus penelitian ini. Secara kualitatif, ungkapan ngambol dideskripsikan dan menjadi tujuan penelitian dalam tulisan ini. 100 responden dipilih sebagai sampel penelitian secara acak dari total populasi masyarakat Melayu Pontianak Kalimantan Barat. Penelitian ini menggunakan statistika deskriptif. Data dikumpulkan melalui angket atau kuesioner dan dianalisis melalui tabulasi statistical product and service solution (SPSS) berdasarkan skala likert yaitu: sangat tidak setuju (1), tidak setuju (2), ragu-ragu (3), setuju (4), dan sangat setuju (5). Berdasarkan data tersebut dapat disimpulkan bahwa 36\% masyarakat Melayu Pontianak setuju bahkan sangat setuju untuk mengungkapkan kemarahannya dalam bentuk ngambol dalam lingkungan pergaulan terdekatnya.

Kata kunci: ungkapan kemarahan, Melayu Pontianak, Kalimantan Barat, ngambol.
\end{abstract}

\begin{abstract}
There are five expression in the society of Pontianak Malay Kalimantan Barat in expressing their anger, that are: nyumpah, nyeranah, beleter, pendek tongkeng, and ngambol. These anger expressions are different in their daily application. Ngambol is ironic in anger expression character since it is not express direct anger but agreeing their speaking partner with special facial expression and voice tone to show disagreement of the spoken statement. Ngambol becomes the focus of this research. Qualitatively, ngambol is described and become the aim of the research. 100 respondents selected randomly from the total population of the
\end{abstract}


Tuah Talino

Tahun XIV Volume 14 Nomor 2 Edisi 4 Desember 2020

ISSN 0216-079X E-ISSN 2685-3043

Balai Bahasa Kalimantan Barat

society of Pontianak Malay Kalimantan Barat to be the sample of the research. This study applied descriptive statistics. The data collected and disseminated through questionnaires and analyzed through tabulation of statistical product and service solution (SPSS) based on the Likert scale which are: strongly disagree (1), disagree (2), doubtful (3), agree (4), and strongly agree (5). Based on the data, it could be concluded that $36 \%$ society of Pontianak Malay respondents agree even strongly agree to express their anger through ngambol in their closest social environment.

Keywords: anger expressions, Pontianak Malay, Kalimantan Barat, ngambol.

\section{PENDAHULUAN}

Bahasa mempunyai fungsi sangat hakiki dalam hubungan antar manusia. Sebagai pengantar saat berhubungan, kerja sama antar manusia hampir mustahil dilakukan dengan optimal tanpa kehadiran bahasa yang benar-benar hadir sebagai piranti komunikasi dan interaksi (Sudaryanto:1990). Selanjutnya, sebagai makhluk sosial manusia tentu tak bisa menghindar untuk selalu berinteraksi dan berkomunikasi dengan sesamanya.

Proses interaksi antar sesama manusia ini akan diekspresikan dalam berbagai rupa rasa, seperti perasaan peduli, sayang, cinta, akrab, hingga marah. Ekspresi terakhir ini yang akan dibahas lebih dalam dalam tulisan ini. Dalam berbagai aktivitas kita sehari-hari, ekspresi atau ungkapan kemarahan tak jarang kita temukan bahkan kita alami sendiri, misal ketika kita tidak menyetujui sesuatu, berselisih pendapat, hingga kesalahpahaman. Ungkapan kemarahan ini akan terwakili dari diri secara eksplisit atau tidak, bisa verbal maupun nonverbal.

Ungkapan kemarahan yang sangat mudah kita temukan atau bahkan ekspresikan biasanya juga dilengkapi dengan mata melotot, bibir mencibir kadang hingga monyong, suara meninggi, bahkan wajah yang memerah. Menarik untuk diteliti bahkan dianggap salah satu ekspresi kemarahan yang paling tinggi adalah diam. Konon, jika seseorang sudah diam, itu tandanya kemarahannya sudah mencapai puncak. Dari dasar-dasar yang disampaikan inilah keragaman ungkapan kemarahan menjadi kajian dan studi yang menarik.

Berbagai kajian telah dilakukan mengenai eksresi kemarahan. Khusus mengenai ekspresi kemarahan dalam masyarakat Melayu Pontianak di Kalimantan Barat, catatan kajian mengenai hal ini pun telah ditemukan. Lubna (2011a) pada penelitian sebelumnya telah menulis tentang salah satu ekspresi kemarahan yaitu beleter. Ternyata beleter merupakan satu sikap marah dapat menjadi upaya pemertahanan budaya Melayu melalui ekspresi-ekspresi kemarahan yang ditampakkan oleh penuturnya. Ungkapan ekspresi ini selain mewariskan kearifan lokal dari orang-orang Melayu yang usianya lebih tua kepada orang Melayu yang berusia lebih muda, juga turut memertahankan serta memartabatkan bahasa 
Tuah Talino

Tahun XIV Volume 14 Nomor 2 Edisi 4 Desember 2020

ISSN 0216-079X E-ISSN 2685-3043

Balai Bahasa Kalimantan Barat

Melayu itu sendiri untuk dapat terus eksis di Pontianak, Kalimantan Barat (Lubna, 2011b).

Lebih jauh, ekspresi atau ungkapan kemarahan dalam masyarakat Melayu Pontianak telah dideskripsikan menjadi lima ungkapan (Lubna: 2016). Ia mendeskripsikan kelima ungkapan itu, yaitu beleter, ngambol, nyumpah nyeranah, dan pendek tongkeng. Hasil penelitian yang telah disampaikan di atas dapat dijadikan sumber referensi pengetahuan tentang ekspresi atau ungkapan kemarahan masyarakat Melayu Pontianak. Namun, pendeskripsikan baru bersifat kualitatif, hasil penelitian memaparkan bagaimana masyarakat Melayu mengungkapkan rasa marahnya.

Data kuantitatif juga diperlukan untuk menjabarkan ungkapan kemarahan ini. Data ini akan dipaparkan dalam bentuk angka dan persentase dilengkapi dengan tabel dan deskripsinya. Hal ini tentu diperlukan untuk memperjelas gambaran umum bagaimana masyarakat Melayu Pontianak mengekspresikan kemarahannya dalam kehidupan sehari-hari.

Lubna telah melengkapi bagaimana masyarakat Melayu Pontianak Kalimantan Barat mengungkapkan kemarahan dalam bentuk nyumpah (2019a) dan beleter (2019b). Persentase angka yang terangkum dalam penelitian ini dapat menjadi rujukan dalam pemetaan sikap bahasa masyarakat penutur Melayu Pontianak.

Itu sebabnya, tujuan penelitian ini juga melengkapi data mengenai ungkapan kemarahan tersebut. Masalah dalam penelitian ini adalah ungkapan kemarahan masyarakat penutur bahasa Melayu Pontianak, khususnya pada ungkapan kemarahan yang disebut ngambol. Pertanyaan "Bagaimana ungkapan kemarahan masyarakat Melayu Pontianak Kalimantan Barat dalam bentuk ngambol?" diharapkan dapat dijawab dalam simpulan dan menambah wawasan pengetahuan dalam ilmu linguistik.

Ngambol adalah ungkapan kemarahan bersifat tidak frontal karena mengucapkan suatu hal dengan nada suara mendayu-dayu dan lembut tetapi menekankan kata atau kalimat dengan maksud sebaliknya atau yang hendak diambol. Pada gaya bahasa Indonesia, hal ini mirip dengan yang kita kenal sebagai majas ironi. Pada masyarakat Melayu Pontianak, ngambol lebih sering dilakukan oleh ibu. Ungkapan kemarahan ini tak hanya diterapkan dalam ranah keluarga namun juga pada lingkungan masyarakat terdekat seperti pada sosialisasi sehari-hari atau hubungan antar teman. Tulisan ini akan memperlihatkan apakah masyarakat Melayu Pontianak Kalimantan Barat masih melakukan ngambol atau tidak. 
Tuah Talino

Tahun XIV Volume 14 Nomor 2 Edisi 4 Desember 2020

ISSN 0216-079X E-ISSN 2685-3043

Balai Bahasa Kalimantan Barat

\section{METODE}

Tulisan ini menggunakan pendekatan penafsiran deskriptif dalam bentuk statistika deskriptif. Penafsiran deskriptif dalah ilmu cabang statistika yang berkaitan dengan prosedur-prosedur yang digunakan untuk menjelaskan karakteristik data secara umum (Kusnandar, dkk, 2019:10). Statistika data yang digunakan dalam tulisan ini yaitu saat mengelompokkan, menyederhanakan, dan menyajikan data ke dalam bentuk yang mudah dimengerti dalam bentuk tabel. Kemudahan dalam memahami data memungkinkan pengguna data untuk dapat menggali lebih banyak informasi tentang karakteristik data, yang biasanya tidak terlihat dalam tampilan data mentahnya.

Berikutnya, penelitian yang mengambil sampel dari populasi dan mengumpulkan data melalui survei dengan kuesioner sebagai alat pengumpul data yang pokok. Penerapan metode ini bertujuan untuk menggambarkan dan menafsirkan hal yang berkenaan dengan suatu kondisi atau gejala seperti apa adanya atau mendeskripsikan gejala faktual dan kaitan berbagai variabel masalah yang diteliti secara sistematis.

\section{Sumber Data dan Data}

Populasi masyarakat penutur bahasa Melayu Pontianak, baik laki-laki maupun perempuan merupakan sumber data dalam penelitian ini. Sejalan dengan pendapat Ahsen (dalam Mahsun, 2005:210) yang menyebutkan bahwa penelitian sosiolinguistik yang hasilnya telah diterbitkan ternyata menggunakan sampel dalam jumlah yang tidak besar. Itu sebabnya sampel atau data yang digunakan dalam penelitian ini dipilih sejumlah 100 (seratus) orang dari sumber data atau populasi yang mewakili masyarakat Melayu Pontianak Kalimantan Barat.

Penentuan data penelitian dilakukan secara acak (random sample) sesuai dengan penjelasan Kusnandar, dkk (2019:93) sehingga anggota populasi mempunyai kesempatan yang sama untuk terpilih sebagai anggota sampel. Penentuan data dilakukan dengan menyebar tautan kuesioner dalam waktu tiga hari melalui kelompok-kelompok percakapan dalam media sosial what's up yang mempunyai basis anggota penutur bahasa Melayu Pontianak.

\section{Profil Data}

Data atau sampel penelitian atau selanjutkan akan disebut sebagai responden adalah masyarakat yang menuturkan bahasa Melayu Pontianak. Responden penelitian terdiri atas laki-laki yang berjumlah 28 orang dan perempuan yang berjumlah 72 orang. Responden penelitian terdiri atas 5 orang yang berusia kurang atau sama dengan 17 tahun, 31 orang berusia 18-25 tahun, 26 orang berusia 26 sampai dengan 35 tahun. Responden dengan rentang usia 36-45 tahun berjumlah 31 orang, responden dengan rentang usia 46 sampai dengan 55 tahun 
Tuah Talino

Tahun XIV Volume 14 Nomor 2 Edisi 4 Desember 2020

ISSN 0216-079X E-ISSN 2685-3043

Balai Bahasa Kalimantan Barat

berjumlah 4 orang, dan responden dengan rentang usia 56-65 tahun berjumlah 1 orang. Yang terakhir, responden dengan rentang usia diatas 65 tahun berjumlah 2 orang.

17 orang responden tinggal di kawasan Pontianak Timur, 19 orang di kawasan Pontianak Barat, 33 orang di kawasan Pontianak Kota, 10 orang di kawasan Pontianak Tenggara, 17 orang di kawasan Pontianak Selatan dan 4 orang di kawasan Pontianak Utara.

\section{Validitas dan Reliabilitas}

Teknik pengolahan data dalam penelitian ini menggunakan penghitungan komputasi program SPSS (Statistical Product and Service Solution) karena program ini memiliki kemampuan analisis statistik cukup tinggi serta sistem manajemen data pada lingkungan grafis menggunakan menu-menu deskriptif dan kotak-kotak dialog sederhana, sehingga mudah dipahami cara pengoperasiannya

Uji validitas dan reliabilitas item kuesioner dalam penelitian ini menggunakan SPSS. Berdasarkan uji validitas dalam SPSS semua item valid untuk dijadikan instrumen pengumpulan data. Selanjutnya uji reliabilitas SPSS menggunakan tehnik split half menyatakan semua item kuesioner yang disebarkan dalam penelitian tergolong reliabel.

\section{Teknik Analisis Data}

Statistika deskriptif dilakukan karena setiap set data hampir dapat dipastikan mempunyai keragaman atau variasi, tidak semuanya bernilai sama atau dengan kata lain terdapat nilai pengamatan yang berbeda dengan nilai pengamatan lainnya. Akan tetapi, keragaman nilai-nilai pengamatan tersebut seringkali mengikuti suatu pola atau bentuk tertentu yang khas, yang merupakan ciri atau karakteristik data.

Kusnandar (2019:10) juga mengatakan bahwa statistik deskriptif digunakan untuk mengelompokkan, menyederhanakan, dan menyajikan data ke dalam bentuk yang mudah dimengerti. Pada penelitian ini, metode statistika deskriptif yang digunakan adalah tabel. Penyajian data dalam tulisan ini dalam bentuk tabel yang bertujuan untuk mengelompokkan nilai-nilai pengamatan ke dalam beberapa kelompok yang masing-masing mempunyai karakteristik yang sama.

\section{PEMBAHASAN}

Ungkapan kemarahan yang dideskripsikan adalah ungkapan kemarahan dalam bentuk ngambol. Terdapat tiga pernyataan berkaitan dengan ungkapan kemarahan dalam bentuk ini. Pernyataan pertama yaitu saya ngambol untuk menunjukkan ketidaksetujuan saya terhadap sesuatu. Reaksi responden terhadap pernyataan ini tampak pada tabel bawah ini. 
Tuah Talino

Tahun XIV Volume 14 Nomor 2 Edisi 4 Desember 2020

ISSN 0216-079X E-ISSN 2685-3043

Balai Bahasa Kalimantan Barat

Tabel 1. Saya ngambol untuk menunjukkan ketidaksetujuan saya terhadap sesuatu

\begin{tabular}{|l|r|r|r|}
\hline & Frekuensi & Persentase & $\begin{array}{r}\text { Persentase } \\
\text { Kumulatif }\end{array}$ \\
\hline Valid Sangat Tidak Setuju & 6 & 6.0 & 6.0 \\
Tidak Setuju & 32 & 32.0 & 38.0 \\
Ragu-ragu & 21 & 21.0 & 59.0 \\
Setuju & 34 & 34.0 & 93.0 \\
Sangat Setuju & 7 & 7.0 & 100.0 \\
Total & 100 & 100.0 & \\
\hline
\end{tabular}

Pernyataan responden pada pertanyaan pertama yaitu enam responden sangat tidak setuju terhadap pernyataan ini. Artinya persentase paling kecil sebesar 6 persen juga merupakan responds responden yang menyatakan sangat tidak setuju untuk ngambol saat menunjukkan ketidaksetujuannya. Jauh berbeda dengan yang tidak setuju yaitu sebesar 32 persen atau 32 responden tidak setuju untuk ngambol saat menunjukkan ketidaksetujuannya terhadap sesuatu. 21 responden yang menyatakan ragu-ragu dan respon terbesar sebanyak 34 responden setuju bahkan sangat setuju yaitu tujuh persen responden yang menyatakan ketidaksetujuannya terhadap sesuatu dengan cara ngambol.

Selanjutnya, saya ngambol pada orang yang dekat dengan saya adalah bunyi pernyataan kedua dalam angket yang disebar pada responden. Reaksi responden terhadap pernyataan ini tampak pada tabel di bawah ini.

Tabel 2. Saya ngambol pada orang yang dekat dengan saya

\begin{tabular}{|c|c|c|c|c|}
\hline & & Frekuensi & Persentase & $\begin{array}{l}\text { Persentase } \\
\text { Kumulatif }\end{array}$ \\
\hline \multirow[t]{6}{*}{ Valid } & Sangat Tidak Setuju & 4 & 4.0 & 4.0 \\
\hline & Tidak Setuju & 37 & 37.0 & 41.0 \\
\hline & Ragu-ragu & 18 & 18.0 & 59.0 \\
\hline & Setuju & 26 & 26.0 & 85.0 \\
\hline & Sangat Setuju & 15 & 15.0 & 100.0 \\
\hline & Total & 100 & 100.0 & \\
\hline
\end{tabular}

Jumlah responden yang sangat tidak setuju pada item pernyataan di atas sebesar 4 persen atau terdapat empat responden yang bereaksi sangat tidak setuju untuk ngambol pada orang yang dekat dengannya. Selanjutnya, 37 responden tidak jauh berbeda dengan bereaksi tidak setuju untuk ngambol pada orang yang 
Tuah Talino

Tahun XIV Volume 14 Nomor 2 Edisi 4 Desember 2020

ISSN 0216-079X E-ISSN 2685-3043

Balai Bahasa Kalimantan Barat

dekat dengannya. 18 responden ragu untuk menyatakan apakah mereka akan ngambol atau tidak ngambol pada orang yang dekat dengan mereka. Sedangkan 26 responden setuju dan 15 responden lainnya sangat setuju menyatakan bahwa mereka ngambol pada orang yang dekat dengan mereka.

Jumlah persentase pada tabel pernyataan ini, senilai dengan jumlah tanggapan responden pada pernyataan yang dibagi, yaitu: empat persen responden sangat tidak setuju untuk ngambol pada orang yang dekat dengannya. Selanjutnya, secara persentase 37 persen responden tidak setuju untuk ngambol pada orang yang dekat dengan mereka. Berikutnya, 18 persen responden merasa ragu untuk ngambol pada orang yang dekat dengan mereka. Persentase responden setuju yaitu sebesar 26 persen dan persentase responden sangat setuju sebesar 15 persen terhadap pernyataan saya ngambol pada orang yang dekat dengan saya.

Pernyataan terakhir mengenai ngambol yaitu pernyataan ketiga pada yang menyatakan bahwa saya ngambol pada orang yang tidak dekat dengan saya. Tabel yang memperlihatkan reaksi responden terhadap pernyataan ini adalah sebagai berikut.

Tabel 1. Saya ngambol pada orang yang tidak dekat dengan saya

\begin{tabular}{|ll|r|r|r|}
\hline & Frekuensi & Persentase & $\begin{array}{r}\text { Persentase } \\
\text { Kumulatif }\end{array}$ \\
\hline Valid & Sangat Tidak Setuju & 10 & 10.0 & 10.0 \\
& Tidak Setuju & 48 & 48.0 & 58.0 \\
Ragu-ragu & 20 & 20.0 & 78.0 \\
Setuju & 22 & 22.0 & 100.0 \\
Total & 100 & 100.0 & \\
\hline
\end{tabular}

Pada tabel di atas, jumlah responden yang sangat tidak setuju untuk ngambol pada orang yang tidak dekat dengan mereka berjumlah 10 responden. Jumlah terbesar tampak pada reaksi tidak setuju yang tampak pada tabel, yaitu 48 responden menyatakan tidak setuju untuk ngambol pada orang yang tidak dekat dengan mereka. Selanjutnya, sejumlah 20 responden merasa ragu untuk menyatakan apakah mereka akan ngambol atau tidak ngambol pada orang yang tidak dekat dengan mereka. Terakhir terdapat 22 responden yang menyatakan setuju bahwa mereka ngambol pada orang yang tidak dekat dengan mereka. Tidak ada yang menjawab sangat setuju pada pernyataan saya ngambol pada orang yang tidak dekat dengan saya.

Pada tabel juga memperlihatkan tanggapan reaksi responden secara persentase yang berbanding lurus dengan jumlah reaksi sebelumnya. Pada tabel terlihat bahwa nol persen sangat setuju untuk ngambol pada orang yang tidak 
Tuah Talino

Tahun XIV Volume 14 Nomor 2 Edisi 4 Desember 2020

ISSN 0216-079X E-ISSN 2685-3043

Balai Bahasa Kalimantan Barat

dekat dengannya. Selanjutnya secara berturut-turut, 10 persen responden sangat tidak setuju, 48 persen responden tidak setuju dan 20 persen responden merasa ragu dan 22 persen responden setuju menyatakan bahwa mereka ngambol pada orang yang tidak dekat dengan mereka.

\section{PENUTUP}

Tiga pernyataan responden di atas selanjutnya diakumulasikan untuk menunjukkan tentang ungkapan kemarahan dalam bentuk ngambol dalam masyarakat Melayu Pontianak Kalimantan Barat. Terdapat 82 respons setuju atau $27 \%$ responden setuju dan 22 respons sangat setuju atau $7 \%$ responden yang sangat setuju untuk menyatakan bahwa mereka ngambol untuk menunjukkan ketidaksetujuannya terhadap sesuatu. Pada dasarnya, ungkapan kemarahan dalam bentuk ngambol dapat dilakukan pada orang yang tidak dekat maupun dekat dengan penutur. Namun, ngambol lebih sering atau lebih efektif ditujukan pada orang yang dekat, 20 respons (7\%) sangat tidak setuju dan 117 tanggapan (39\%) tidak setuju ngambol dilakukan pada orang yang tidak dekat dengan penutur.

Berdasarkan respons yang tampak pada sikap marah ngambol dapat peneliti simpulkan bahwa respons sangat tidak setuju dan tidak setuju lebih unggul (46\%) dibanding setuju dan sangat setuju (34\%). Terdapat keraguan yang cukup tinggi senilai 20\% tanggapan responden mengenai sikap ngambol ini. Pada masingmasing tanggapan dalam pernyataan tampak bahwa ngambol masih dilakukan dalam masyarakat Melayu terutama diantara orang-orang terdekat. Angka keraguan yang cukup besar (20\%) bisa jadi disebabkan karena ungkapan kemarahan dalam bentuk ngambol sendiri merupakan ungkapan kemarahan yang tidak terlalu populer dalam masyarakat Melayu Pontianak terutama yang berusia belia. Bahkan sebagian responden berusia muda mengakui menerka-nerka definisi ngambol dan bertanya pada orang tuanya tentang arti yang sebenarnya, ada juga yang rancu antara kata ngambol yang berasosiasi dengan marah dan tambol yang berasosiasi penganan.

Selanjutnya, sejalan dengan bagian publikasi lain mengenai ungkapan kemarahan ini yang dimuat dalam tulisan sebelumnya (Lubna: 2019ab) terdapat beberapa saran rekomendasi hal-hal terkait penelitian ini, yaitu sebagai berikut.

1) Penelitian ini dapat dilanjutkan dengan sampel lebih banyak dengan rentang pernyataan lebih luas sehingga analisis dan simpulan yang lebih komprehensif mengenai alasan kenapa ungkapan kemarahan dalam bentuk ngambol ini masih dilakukan atau bahkan tidak dilakukan lagi terungkap lebih jelas.

2) Penelitian lanjutan dengan menggunakan analisis variabel berbeda juga dapat menjadi fokus penelitian lanjutan karena hasil penelitian ini baru membahas 
ungkapan kemarahan secara umum yang terjadi di masyarakat Melayu Pontianak Kalimantan Barat. Pengerucutan analisis dengan menggunakan krostabulasi pada data ordinal responden, seperti: jenis kelamin, usia, status, lokasi tempat tinggal, bidang pekerjaan, bahasa pertama dan kedua, dan atau latar belakang keluarga juga dapat menjadi bahasan menarik yang lebih terpumpun pada penelitian lanjutan.

3) Penelitian korelasi juga bisa menjadi pilihan jika pihak lain ingin membuat penelitian lanjutan mengenai relasi atau hubungan antara pengetahuan terhadap ungkapan kemarahan dengan sikap bagaimana mengungkapkan kemarahan tersebut dalam masyarakat Melayu Pontianak Kalimantan Barat.

Berbagai penelitian ini dapat menjadi rujukan pengetahuan yang sangat rinci dan akomodatif mengenai bagaimana suatu suku dalam hal ini suku atau masyarakat Melayu Pontianak Kalimantan Barat mengekspresikan atau mengungkapkan kemarahannya. Dasar pengetahuan ini sejatinya dapat mencegah konflik karena saling memahami tentang cara bersikap dan bertutur termasuk cara marah.

Pengetahuan tentang ungkapan kemarahan dalam bentuk ngambol yang misalnya dapat memberikan pemahaman bahwa tidak semua kalimat yang berbunyi pengakuan menggambarkan kesetujuan atas suatu hal. Bisa jadi hal itu (sebagaimana yang tampak dalam hasil penelitian mengenai ungkapan kemarahan ngambol ini) mencerminkan ketidaksetujuan atas pernyataan yang disebutkan. Atas dasar pemahaman yang baik mengenai hal ini, konflik karena kekurangpahaman terhadap sesuatu tentu dapat diminimalisasi dan kerukunan antar suku dalam kehidupan multietnis di Indonesia selalu terjaga dan terpelihara.

\section{DAFTAR PUSTAKA}

Kusnandar, D. dkk. (2019). Metode Statistika serta Aplikasinya dengan Minitab, Excel dan R. Pontianak: Untan Press.

Lubna, S. (2011). Beleter for Transfering Language and Cultural Moral Values to Young Malays at Pontianak, Kalimantan Barat dalam Timothy Mc Kinnon, dkk (ed): 251-255. International Seminar Proceeding: Language Maintenance and Shift. Semarang: Master's Program in Linguistics, Diponegoro University.

Lubna, S. (2011). Beleter Pemertahanan Budaya Melayu dalam Ekspresi Kemarahan dalam Subyantoro, dkk (ed): 73-78. Prosiding Bahasa dan Sastra. Semarang: Universitas Negeri Semarang. 
Tuah Talino

Tahun XIV Volume 14 Nomor 2 Edisi 4 Desember 2020

ISSN 0216-079X E-ISSN 2685-3043

Balai Bahasa Kalimantan Barat

Lubna, S. (2016). Ekspresi Kemarahan dalam Bahasa Melayu Pontianak Kalimantan Barat-Ekspression of Anger in Pontianak Malay West Kalimantan. Tuah Talino, 10(8), 60-68.

Lubna, S. (2019a). Nyumpah: Ungkapan Kemarahan Masyarakat Melayu Pontianak Kalimantan Barat-Nyumpah: Anger Expression in the Society of Pontianak Malay Kalimantan Barat. Tuah Talino, 13(2), 270-282.

Lubna, S. (2019b). Ungkapan Dalam Bentuk Beleter Masyarakat Melayu Pontianak Kalimantan Barat-Anger Expression in Beleter of the Society of Pontianak Malay Kalimantan Barat dalam Lubna, dkk (ed): 95-107. Prosiding Seminar Hasil Penelitian Kebahasaan dan Kesastraan: Pemartabatan Bahasa dan Sastra Indonesia: Pontianak: Balai Bahasa Kalimantan Barat.

Mahsun, M.S. (2005). Metode Penulisan Bahasa: Tahapan, Strategi, Metode dan Tehniknya. Jakarta: Rajawali Press.

Mahsun, M.S. (2007). Metode Penelitian Bahasa. Tahapan Strategi, Metode, dan Tekniknya. Jakarta: PT RajaGrafindo Persada.

Sudaryanto. (1990). Menguak Fungsi Hakiki Bahasa. Yogyakarta: Duta Wacana University Press.

\section{UCAPAN TERIMA KASIH}

Bapak Christanto Syam dan Ibu Sisilya Saman merupakan pembimbing tulisan yang merupakan satu dari lima bagian Tesis ini. Oleh karena itu, penulis mengucapkan terima kasih tulus kepada kedua pembimbing yang telah berkontribusi pada tulisan ini. 